\title{
Regional Economic Impacts of Biochemical and Pyrolysis Biofuel Production in the Southeastern US: A Systems Modeling Approach
}

\author{
Dayton M. Lambert*, Burton C. English, R. Jamey Menard, B. Wilson \\ Department of Agricultural \& Resource Economics, University of Tennessee Institute of Agriculture, Knoxville, \\ TN, USA \\ Email: "dlamber1@utk.edu
}

Received 30 May 2016; accepted 26 June 2016; published 29 June 2016

Copyright @ 2016 by authors and Scientific Research Publishing Inc.

This work is licensed under the Creative Commons Attribution International License (CC BY). http://creativecommons.org/licenses/by/4.0/

(c) (i) Open Access

\section{Abstract}

This research developed a regional economic model to estimate the ex-ante impacts of biofuel production on the economy of the southeastern United States. The analysis focuses on biofuels produced using biochemical and pyrolysis technologies. The primary feedstocks considered include switchgrass (Panicum virgatum) and poplar (Populus spp.). The economic analysis modifies the Impact Analysis for Planning (IMPLAN) input-output model to determine the macroeconomic impacts of a mature industry producing biofuels using these technologies and feedstocks. Optimal facility locations are determined using a site locator model that minimizes the costs of procuring feedstock. Given a change in the land use caused by industry demand for feedstock, shocks to the farm economy are forward-linked to sectors supporting biofuel production. Key economic indicators analyzed include changes in employment and value added to the economy. System output is analyzed using a nonparametric bootstrap procedure to simulate the distributions of the impacts. The null hypothesis is that the economic impacts following the introduction of the industries are not different from baseline economic activity. Findings suggest that the net changes in employment and value added to the regional economy are positive, but modest. For example, job increases attributed to the advancement of the industries analyzed range between $0.18 \%$ and $0.95 \%$. Total value added to the regional economy ranged between $0.15 \%$ and $0.83 \%$.

\section{Keywords}

Biochemical, Biofuel, Biomass, Economic Impact, Pyrolysis

\footnotetext{
${ }^{*}$ Corresponding author.
} 


\section{Introduction}

Prior research finds that the southeastern (SE) US will be an important supply region for cellulosic biomass feedstocks from dedicated energy crops and from forestry and wood waste sources [1] [2]. Federal mandates set targets for the production of advanced biomass fuels from non-grain materials. The United States Energy Policy Act of 2005 established the Renewable Fuel Standard (RFS). This legislation required that 7.5 billion gallons of domestic transportation fuels originate from renewable sources. The RFS policy was revised two years later (RFS2) through the Energy Independence and Security Act (EISA), mandating that 36 billion gallons per year of biofuels be produced in the United States by 2022, with 21 billion gallons produced with advanced biofuel technologies [3]. Research suggests that $50 \%$ of this target could be produced in the SE US due to growing conditions favorable to variety of biomass materials [4].

This research estimates the change in regional economic indicators, including total value added to the economy and employment, based on annual facility operating, feedstock transport, storage, labor, renewable identification number credits, and the opportunity costs of replacing conventional crops with the feedstocks of switchgrass and/or short rotation woody crops (e.g., poplar). The analysis is ex-ante; in other words, we ask "what if” questions given assumptions pertaining to 1) the economics and technology of converting cellulosic materials to biofuels using biochemical or pyrolysis pathways; 2) the growing conditions for woody biomass and switchgrass in the southeastern US; 3) the distribution of current agricultural land use in the region; and 4) the economic conditions before the placement of drop-in fuel or cellulosic ethanol production facilities. Attracting biofuel production could provide communities off-farm work opportunities and increase household income through linkages to local agricultural production and supporting businesses [5] [6]. In many cases, new biofuel facilities generate employment opportunities, deepen the community's tax base, and increase local spending [7]-[9]. English et al. [10] forecasted that the impact of feedstock conversion to ethanol could exceed \$700 billion USD and create 5.1 million jobs by 2025. Federal agencies estimated that the RFS supporting biomass perennial crops could generate 700,000 jobs and \$88.5 billion in economic activity by 2023 [11].

Research analyzing the effects of biofuel production on local economies is generally characterized by studies applying on input/output (IO) models or econometric studies using primary survey data or secondary "macro" county data. The economic impacts of bioenergy and biofuels development have been analyzed in studies using the economic IO model IMPLAN (the Impact Analysis and Planning system, [12]). IMPLAN is an IO model used to analyze interdependencies between industries in an economy through market-based transactions. The model describes the transfer of money between industries and institutions and contains both market-based and non-market financial flows. Output from the model includes Total Industry Output (TIO) (a measure of economic activity), Total Value-Added (TVA), labor income (a component of value-added), and employment for 440 industries in the study region's economy. Total industry output measures the annual dollar value of goods and services that an industry produces. Employment represents estimated number of full- and part-time wage and salary employees, as well as self-employed. Total Value-Added (TVA) captures estimated employee compensation, proprietary income, other property type income (dividends, interests, rents, corporate profits, and capital depreciation), and tax on production and imports (all business taxes and fees paid to governments including sales and excise taxes).

Lazarus and Tiffany [13] investigated the economic impacts of Short Rotation Woody Crops (SRWC) used to produce energy in Minnesota. English, Menard, and De La Torre Ugarte [14] evaluated the economic impacts of using corn stover for ethanol production for Midwestern states. The impact of bioenergy energy industries on Louisiana's economy was determined using IMPLAN by Hughes and Hinson [15]. Using IO methods, Turner and Kreisel [16] found that so-called "green industries" were the second largest employer in US production agriculture. Swenson [17] found an employment impact multiplier of 3.79 jobs generated for 1 job at an ethanol facility. Low and Isserman [18] estimated an employment multiplier for the construction of ethanol ranging between 3.92 to 6.41 jobs per person employed by an ethanol producing facility.

This analysis develops a system of interrelated modules depicting the linkages between primary feedstock producers, biofuel production, and supporting industries with economy-wide impacts in the SE United States. The core economic model is the IMPLAN IO model, but the system is modified to reflect the opportunity costs of production incurred by landowners and agricultural producers and credits facilities could receive for producing biofuel. The modules are driven by a facility locator model, BioFLAME [19], which determines the optimal location for biofuel facilities based on a cost minimization algorithm. 


\section{Methods and Data}

The technology focus of this analysis is on the production of ethanol and “drop-in” fuels, such as biobutanol. The analysis assumes ethanol is produced through biochemical processes. Drop-in fuels are produced using pyrolysis. Either technology can use switchgrass (Panicum virgatum) or the short rotation woody crop (SRWC), poplar (Populus spp.) as energy feedstocks. Switchgrass is a perennial grass native to the region, and is considered favorable for producing cellulosic ethanol and other advanced biofuel products, depending on the technological pathway [19]. Poplar is a fast-growing hardwood that grows well in the southeastern region and is suitable for producing biomass materials in short crop rotations to produce advanced biofuels and other biobased materials [20]. One product of pyrolysis is biobutanol. Biobutanol is produced from cellulosic biomass and has an efficiency advantage over ethanol because it is easily blended with gasoline and would not require new or modified pipelines, blending facilities, storage tanks, or retail station pumps [21]. Cellulosic “drop-in” transportation fuels like biobutanol can be produced from a variety of biomass sources including sugarcane, maize, tubers, forage sorghum, corn stover, sunflower, forest residues, herbaceous or short rotation woody crops, or cellulose waste. Drop-in fuels can also be produced using advanced hydrolysis and fermentation of lignocellulosic materials to produce cellulosic ethanol.

In cases where an industry must be added to IMPLAN (either the industry does not exist in IMPLAN or it does not exist in the region), the projected value of output and expenditures on inputs and services from the "new" renewable industry are constructed by creating production functions for the industry. When this cost and production data about a type of facility is unavailable, representative facilities must be assumed and custom built into the IO model. Investment and operating costs estimates and production coefficients for conversion facilities are based upon prior studies [22]-[25].

Conversion technology specifications for pyrolysis and cellulosic ethanol are based on Wright et al. [26] and Humbird et al. [27] (Table 1). According to the EIA [28], 681.2 trillion Btu generated from petroleum are required on an annual basis. There are approximately 74,500 Btus/gallon of ethanol. A 50\% replacement rate translates into a feedstock supply target of 10.5 billion gallons per year (bgy) of cellulosic-based fuel produced in the SE region. Assuming a conversion factor of 85 gal ethanol/t of cellulose, the most current techno-economic data suggests an upper capacity limit of about 80 million gallons/year/facility, operating at 96\% efficiency. This translates into 147 cellulosic ethanol plants locating in SE region (Table 1).

For pyrolytic conversion of biomass to drop-in fuels, the Btu/gallon ratio is 118,300, with a conversion rate of 52 gallons/t of biomass material (Table 1). Because of relative energy efficiencies compared to biochemical technology, the 10.5 bgy RFS target is downward adjusted to 6.795 bgy of pyrolysis-related products needed to meet the EISA target of 10.5 bgy at the 50\% replacement rate. The base plant capacity for pyrolysis technology is assumed to be 55.7 million gallons per year (mgy) for switchgrass and poplar. This facility capacity corresponds with 121 production units requiring 78.2 million tons per year of biomass.

Table 1. Carrying capacity summary for cost minimizing sites.

\begin{tabular}{|c|c|c|}
\hline Feedstock/technology & Biochemical & Pyrolysis \\
\hline Switchgrass & $\mathrm{X}$ & $\mathrm{X}$ \\
\hline SRWC (poplar) & $X$ & $\mathrm{X}$ \\
\hline Fuel type & Ethanol & Drop-in \\
\hline BTU fuel value & 74,500 & 118,300 \\
\hline Gallons produced (billions) & 10.5 & 6.795 \\
\hline Conversion rate (fuel product/ton) & 85 & 52 \\
\hline Production a) & 10.5 & 6.795 \\
\hline Feedstock (tons/facility) & 884,506 & 701,329 \\
\hline Base plant capacity (millions gal.) & 80 & 55.7 \\
\hline Plants required meeting target & 147 & 122 \\
\hline
\end{tabular}

Notes: a) assumes $100 \%$ of the 10.5 billion'gallon'year ${ }^{-1}$ target for the southeastern US is met. 
The analysis compares economic indicators with facility locations and corresponding feedstock demand under different policy scenarios, ranging from $22 \%$ fulfillment of the RFS2 mandate to the full, $100 \%$ attainment of the goal. The ethanol and drop-in fuel production levels analyzed (22\%, 31\%, 50\%, and $100 \%$ of the RFS2 mandate) reflect the possibility that the mandate may be only be partially fulfilled, or, alternatively, the growth of the industry over time.

\subsection{Modeling System}

Changes in the economy are driven by biofuel facility demand for feedstock, which impacts the distribution of land allocated to conventional crop production (Figure 1). As the distribution of land changes to meet these requirements, so too does demand for agricultural inputs, land rent, and other productive factors primarily impacting farm-level production. Facilities locating in a region require labor, financial and managerial services, physical materials, energy, and other support. As Figure 1 indicates, these interactions are incurred by feedstock of biofuel producers as costs or returns. These demands are also tied to the wider economy, further impacting jobs, income, and investment in other sectors of the regional economy as depicted in Figure 1 under "economy-wide impacts".

The core components of the IMPLAN model was used to structure these economic impacts. There were 43 industrial sectors identified for the pyrolysis and biochemical-cellulosic fuel technologies using the 2010 IMPLAN data base. There are 55 economic regions according to the Bureau of Economic Analysis (BEA) definitions defining the study area. A separate impact statement is generated for each BEA unit, conditional on the number of facilities locating in a region and the feedstock required by these facilities.

As depicted in Figure 1, feedstock establishment and facility construction costs are one-time investments. All other expenses are recurring annual costs. It is important to adjust impacts when land is removed from the production of conventional crops to the production of feedstock. The opportunity costs forgone by landowners as productive agricultural land is allocated to switchgrass or the production of SRWC are potentially negative impacts (e.g., loss of revenue, $-\mathrm{R}$ ). The costs of forgoing receipts from corn, soybeans, and other crops typical to the region are netted out of gains from the production of feedstock as more land is used to produce biomass.

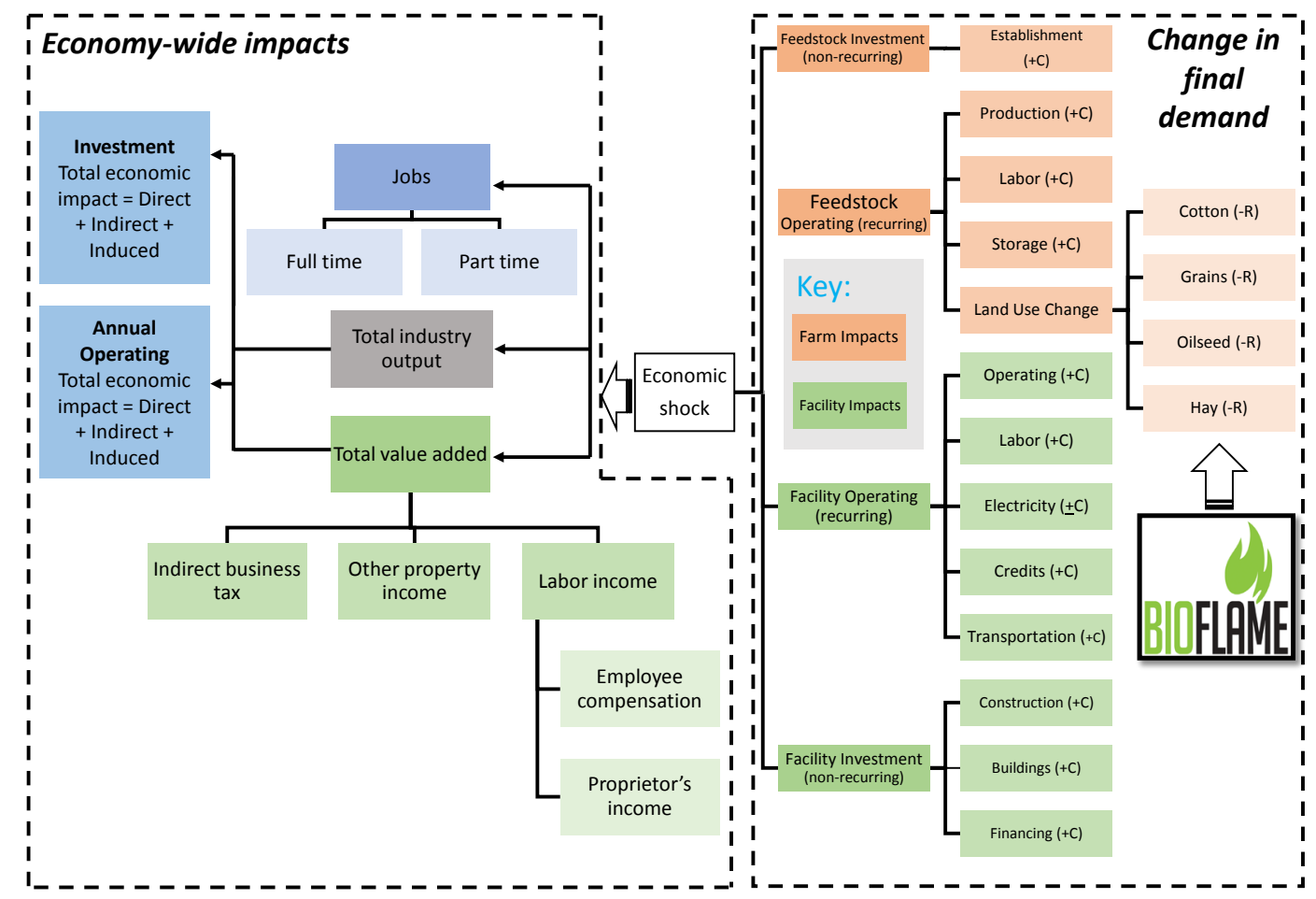

Figure 1. Economic system analyzing industry demand for switchgrass and poplar biomass on regional economic indicators. (Notes: " $-\mathrm{R}$ " indicates a loss in revenue by producers; " $+\mathrm{C}$ ” indicates an additional costs incurred; “ $\pm \mathrm{C}$ ” indicates facility energy costs may increase or decrease, depending on the electricity credits generated by the facility). 
Credits from Renewable Energy Identification Number (RINS) are "pure profit” to facilities and proprietor's income $(+C)$. They occur as a result of product output. Therefore, it is assumed the RIN value is spread throughout the regional economy in a fashion similar to manner in which proprietor income is spent. The costs of transportation and feedstock storage requirements are considered as operating costs and feed into the economy.

\subsection{Site Facility Location System: BioFLAME}

Least-cost facility locations are determined using the site facility locator model, BioFLAME (Figure 2). The BioFLAME model is currently calibrated for 16 southeastern states, and has been used to explore the economic impacts of preprocessing facilities for a commercial-size switchgrass biofuel plant in East Tennessee ([29] [30]) and impacts of biofuels on water quality [19]. BioFLAME operates on GIS architecture consisting of three components-site suitability, feedstock availability, and land conversion. As indicated in Figure 2, road networks, pipelines, transmission lines, and other geo-spatial layers ([31]) are used to identify candidate cellulosic refinery locations. Given an annual target output level for a facility, BiofLAME determines: 1) from where cellulosic feedstock would be sourced to supply the facility, 2) the annual cost of procuring and transporting feedstock, and 3) how many facilities a region can support.

BioFLAME's costs minimization routine integrates GIS functions and database management operations to determine the facility locations minimizing the plant-gate cost of feedstock (Figure 2). Soil productivity and weather impact crop yields. Regional-level crop budgets, acreages, and prices are used to calculate a break-even price above which farmers would convert traditional crops to dedicated energy crops. The shortest route to every potential feedstock supply unit along the transportation network is determined and used to generate a least-cost transportation surface. A hierarchy of primary, secondary, and tertiary roads generates arcs between supply nodes. The feedstock supply analysis subsequently evaluates the costs of siting a facility in the set of all candidate sites in a region. The final solution minimizes transportation and farmgate costs at preferred sites.

Key location determinants used by BioFLAME include transportation networks and the distribution of biomass from agriculture and forests. The distribution of feedstock materials from cropland was updated using the 2010 USDA NASS [32] Cropland Data Layers. As depicted in Figure 2, commodity prices, crop budgets ([33]), and transport costs are the primary drivers of the facility locator model. Costs and yield of growing dedicated energy crops [34], conventional crops (corn, soybean, barley, wheat, oats, hay, and cotton) or pastureland costs

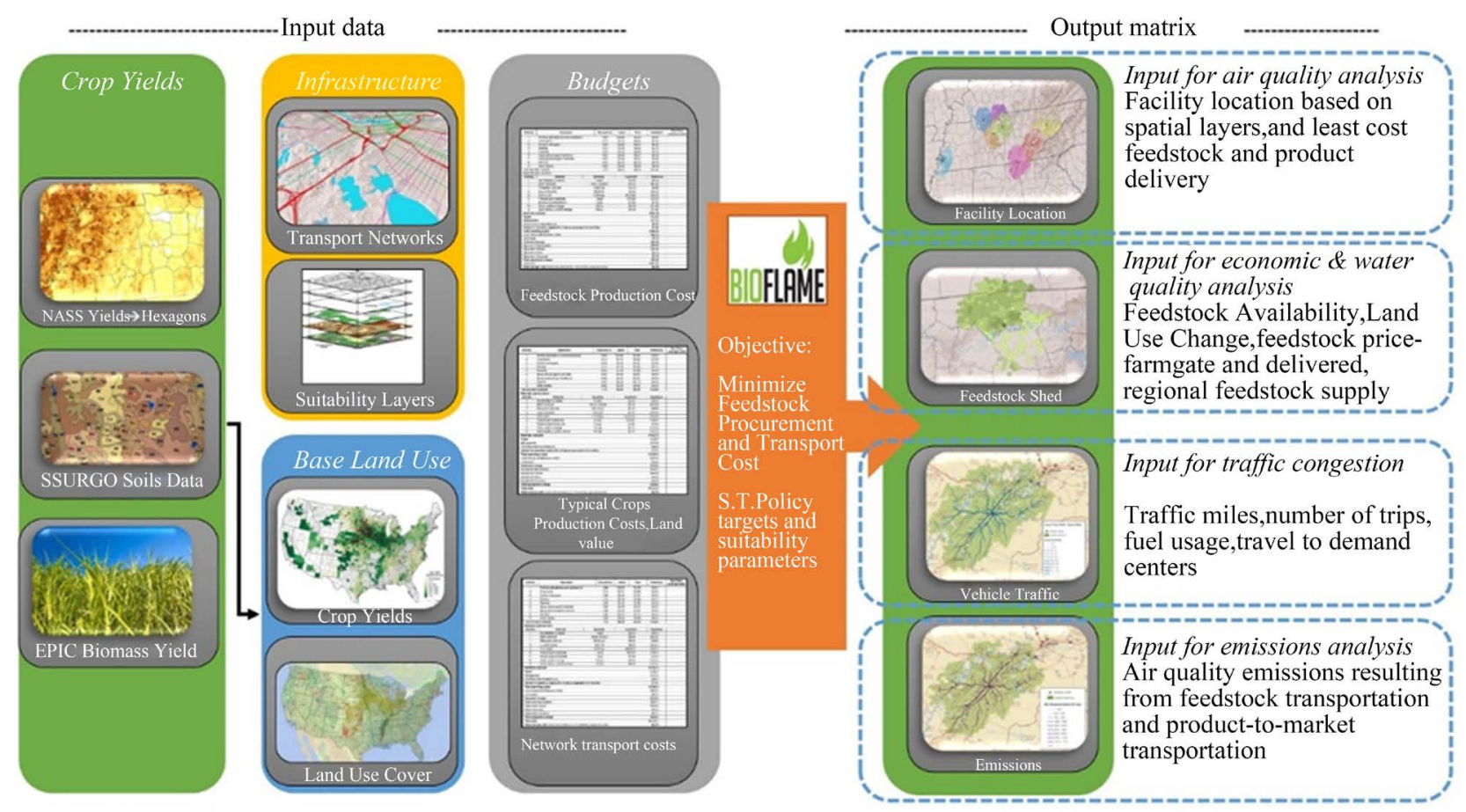

Figure 2. Schematic of site facility locator system, BioFLAME. 
are estimated in similar fashion using regional crop budget to generate a cost surface [35], NASS 2010 annual commodity prices and county level yields modified by soil. A breakeven price of biomass is determined assuming that the biomass crop must at least equal to profit generated by conventional crops or the land rent value of that land based on state level land rent values for non-irrigated cropland or pasture land. The opportunity costs of crop production and pastureland were updated with 2010 commodity prices to reflect these trade-offs [36].

\subsection{Economic Indicators}

The economic indicators analyzed are changes in employment, total value added to the economy (TVA), total industry output (TIO), and labor income. Using the economic data of the 440 industries represented in the 2010 IMPLAN data files, we estimated the 2010 baseline TIO to 6.17 trillion dollars, with an aggregate value added from economic activity of 3.59 trillion \$USD. Total regional employment was 46.51 million jobs, with a labor income of 2.26 trillion \$USD. These indicator levels represent the baseline.

Two measures are used to analyze how these indicators change. The first measure is the percent change from the baseline, aggregate economy of the SE region. The second measure evaluates changes in employment and total value added on a per Btu (energy) equivalent. This metric allows for a relative comparison between biochemical and pyrolysis pathways and their respective impacts on feedstock demand, land use, and the regional economy.

\subsection{Nonparametric Bootstrap Simulation of Indicator Distributions}

A nonparametric bootstrap procedure is used to simulate the distributions of the economic impact indicators to compare point estimates to the baseline economy. The bootstrap is useful when the moment generating function of a distribution is unknown, or when the variance calculation of a function is intractable [37]. In this research, the distribution of an aggregate impact (a sum) is desired.

Let $Z_{0}^{k}$ indicate an aggregate economic measure $k$ such as total employment or total value added for $i=1, \cdots, 55$ BEA regions. The baseline economic level of the $k$ th indicator is therefore $Z_{0}^{k}=\sum_{i=1}^{55} z_{i, 0}^{k}$, with the lower case $z$ an indicator of economic activity in region $i$. The percent change following a shock to the economy is $D^{k}=100 \cdot\left(\Delta Z_{1}^{k} / Z_{0}^{k}\right)$, where $\Delta Z_{1}^{k}$ indicates the change in economic activity following the shock. In the present case, the "shock" driven by site selection, feedstock procurement, and biofuel production occurring in location $i$. The distribution of change $D^{k}$ is simulated with the bootstrap as follows.

1) Resample with replacement indicators $z_{i, 0}^{k}$ to construct a bootstrap sample, $z_{0^{*}}^{k}=\left\{z_{0^{*}}^{1, k}, z_{0^{*}}^{2, k}, \cdots, z_{0^{*}}^{55, k}\right\}$, where “*” indicates the indicator is randomly selected from the observed distribution, and assuming each BEA region has an equally likely chance of selection.

2) From the resampled set $z_{0^{*}}^{k}$, determine the number of facilities locating in a BEA region and the corresponding area allocated to feedstock production with the indicator variable $\omega_{i}$, such that $\omega_{i}$ is the number of facilities locating in economic region $i, 0$ otherwise. The set of indicators corresponding with impacted regions is therefore $\Delta z_{0^{*}}^{k}=\left\{\omega_{1^{*}} \cdot \Delta z_{0^{*}}^{1, k}, \omega_{2^{*}} \cdot \Delta z_{0^{*}}^{2, k}, \cdots, \omega_{55^{*}} \cdot \Delta z_{0^{*}}^{55, k}\right\}$.

3) Determine the aggregate indicator, $Z_{0, m}^{k}=\sum_{i=1}^{55} z_{0^{*}}^{i, k}$. This is the $m$ th bootstrapped baseline indicator.

4) Determine the aggregate indicator, $\Delta Z_{1, m}^{k}=\sum_{i=1}^{55} \omega_{i^{*}} \cdot \Delta z_{0^{*}}^{i, k}$. This is the $m$ th bootstrapped indicator following the economic shock.

5) The statistic $D_{m}^{k}$ is calculated and collected as the $m$ th bootstrapped statistic, for $m=1, \cdots, 10000$ simulations.

A similar resampling strategy was used to simulate the distributions of the impact ratios; employment and value added, per Btu produced from biochemical and pyrolytic technologies and the feedstocks analyzed at each policy target. The medians, lower 5\%-, and upper 95\%-tiles are estimated for each simulated distribution for comparative purposes.

\section{Results and Discussion}

Aggregate economic impacts were modest for all target levels analyzed. Assuming that $100 \%$ of the 10.5 bgy mandate was achieved, aggregate economic impacts were typically less than $1 \%$ for each of the indicators (Table 2). For example, assuming the $100 \%$ goal of 10.5 bgy is achieved using only drop-in fuels produced with 
switchgrass, the aggregate change in jobs is $0.81 \%$ (from a 2010 baseline employment level of 46.51 million in the southeastern US). For pyrolysis using SRWC as feedstock, the corresponding change in total value added to the regional economy was $0.65 \%$ (from a 2010 baseline of $\$ 3.59$ trillion). For cellulosic ethanol produced using switchgrass as feedstock, the change in employment and total value added to the economy was $0.97 \%$ and $0.84 \%$, respectively. The indicators evaluated at targets below the $100 \%$ goal suggest that the indices are strongly influenced by transport costs (Table 2). The decreases reflect the premium associated with least cost sites as they are sequentially occupied by entering firms.

As indicated by the simulated distributions, the shocks are significantly different from the baseline economy (Figure 3 and Figure 4). Generally, target achievement and economic impacts are inversely related because transport costs increase as prime feedstock production locations are exhausted (Figure 3). The impacts also vary depending on the degree to which a localized economy is linked to other sectors and other regions, as exhibited in Figure 3 and Figure 4. The variation around the point estimates tends to increase advancing towards the 10.5 bgy target. This is most notable for the switchgrass-biochemical ethanol technology. However, the variability associated with each simulated point estimate suggests the impacts aggregate impacts generated by the different technology/feedstock combinations are similar.

Impacts are expected to be larger in areas where economic linkages to other sectors of the economy are denser. In addition, areas with stronger ties to conventional agricultural production (typically rural areas away from urban centers) could experience negative impacts on the agricultural sector as traditional crops are displaced by feedstock production. The pyrolysis facilities are, ceteris paribus, smaller in scale compared with the biochemical

Table 2. Percentage change from baseline economy.

\begin{tabular}{|c|c|c|c|c|}
\hline & $100 \%$ target & & Labor & Total value \\
\hline Fuel/technology/feedstock: & $\underline{\mathrm{TIO}}^{\mathrm{a}}$ & ${\underline{\text { Jobs }^{\mathrm{b}}}}^{\mathrm{L}}$ & Income $^{\mathrm{c}}$ & $\underline{\text { Added }}^{\mathrm{d}}$ \\
\hline Ethanol/Biochem./Switchgrass & $0.77 \%$ & $0.97 \%$ & $0.80 \%$ & $0.84 \%$ \\
\hline Ethanol/Biochem./SRWC & $0.65 \%$ & $0.81 \%$ & $0.70 \%$ & $0.72 \%$ \\
\hline Drop-in (pyrolysis)/SRWC & $0.61 \%$ & $0.76 \%$ & $0.65 \%$ & $0.65 \%$ \\
\hline \multirow[t]{2}{*}{ Drop-in (pyrolysis)/Switchgrass } & $0.68 \%$ & $0.81 \%$ & $0.70 \%$ & $0.72 \%$ \\
\hline & $50 \%$ target & & Labor & Total value \\
\hline Fuel/technology/feedstock: & $\underline{\mathrm{TIO}}^{\mathrm{a}}$ & ${\underline{\text { Jobs }^{\mathrm{b}}}}^{\mathrm{L}}$ & $\underline{\text { Income }}^{\mathrm{c}}$ & $\underline{\text { Added }}^{\mathrm{d}}$ \\
\hline Ethanol/Biochem./Switchgrass & $0.40 \%$ & $0.50 \%$ & $0.41 \%$ & $0.43 \%$ \\
\hline Ethanol/Biochem./SRWC & $0.34 \%$ & $0.42 \%$ & $0.33 \%$ & $0.36 \%$ \\
\hline Drop-in (pyrolysis)/SRWC & $0.31 \%$ & $0.40 \%$ & $0.33 \%$ & $0.33 \%$ \\
\hline \multirow[t]{2}{*}{ Drop-in (pyrolysis)/Switchgrass } & $0.34 \%$ & $0.41 \%$ & $0.35 \%$ & $0.36 \%$ \\
\hline & $31 \%$ target & & Labor & Total value \\
\hline Fuel/technology/feedstock: & $\underline{\mathrm{TIO}}^{\mathrm{a}}$ & ${\underline{\text { Jobs }^{\mathrm{b}}}}$ & Income $^{\mathrm{c}}$ & $\underline{\text { Added }}^{\mathrm{d}}$ \\
\hline Ethanol/Biochem./Switchgrass & $0.24 \%$ & $0.31 \%$ & $0.25 \%$ & $0.26 \%$ \\
\hline Ethanol/Biochem./SRWC & $0.20 \%$ & $0.25 \%$ & $0.20 \%$ & $0.21 \%$ \\
\hline Drop-in (pyrolysis)/SRWC & $0.20 \%$ & $0.25 \%$ & $0.20 \%$ & $0.20 \%$ \\
\hline \multirow[t]{2}{*}{ Drop-in (pyrolysis)/Switchgrass } & $0.22 \%$ & $0.26 \%$ & $0.22 \%$ & $0.23 \%$ \\
\hline & $22 \%$ target & & Labor & Total value \\
\hline Fuel/technology/feedstock: & $\underline{\mathrm{TIO}}^{\mathrm{a}}$ & $\underline{\mathrm{Jobs}}^{\mathrm{b}}$ & $\underline{\text { Income }}^{\mathrm{c}}$ & $\underline{\text { Added }}^{\mathrm{d}}$ \\
\hline Ethanol/Biochem./Switchgrass & $0.17 \%$ & $0.22 \%$ & $0.18 \%$ & $0.19 \%$ \\
\hline Ethanol/Biochem./SRWC & $0.16 \%$ & $0.19 \%$ & $0.16 \%$ & $0.17 \%$ \\
\hline Drop-in (pyrolysis)/SRWC & $0.16 \%$ & $0.20 \%$ & $0.16 \%$ & $0.16 \%$ \\
\hline Drop-in (pyrolysis)/Switchgrass & $0.16 \%$ & $0.19 \%$ & $0.16 \%$ & $0.17 \%$ \\
\hline
\end{tabular}



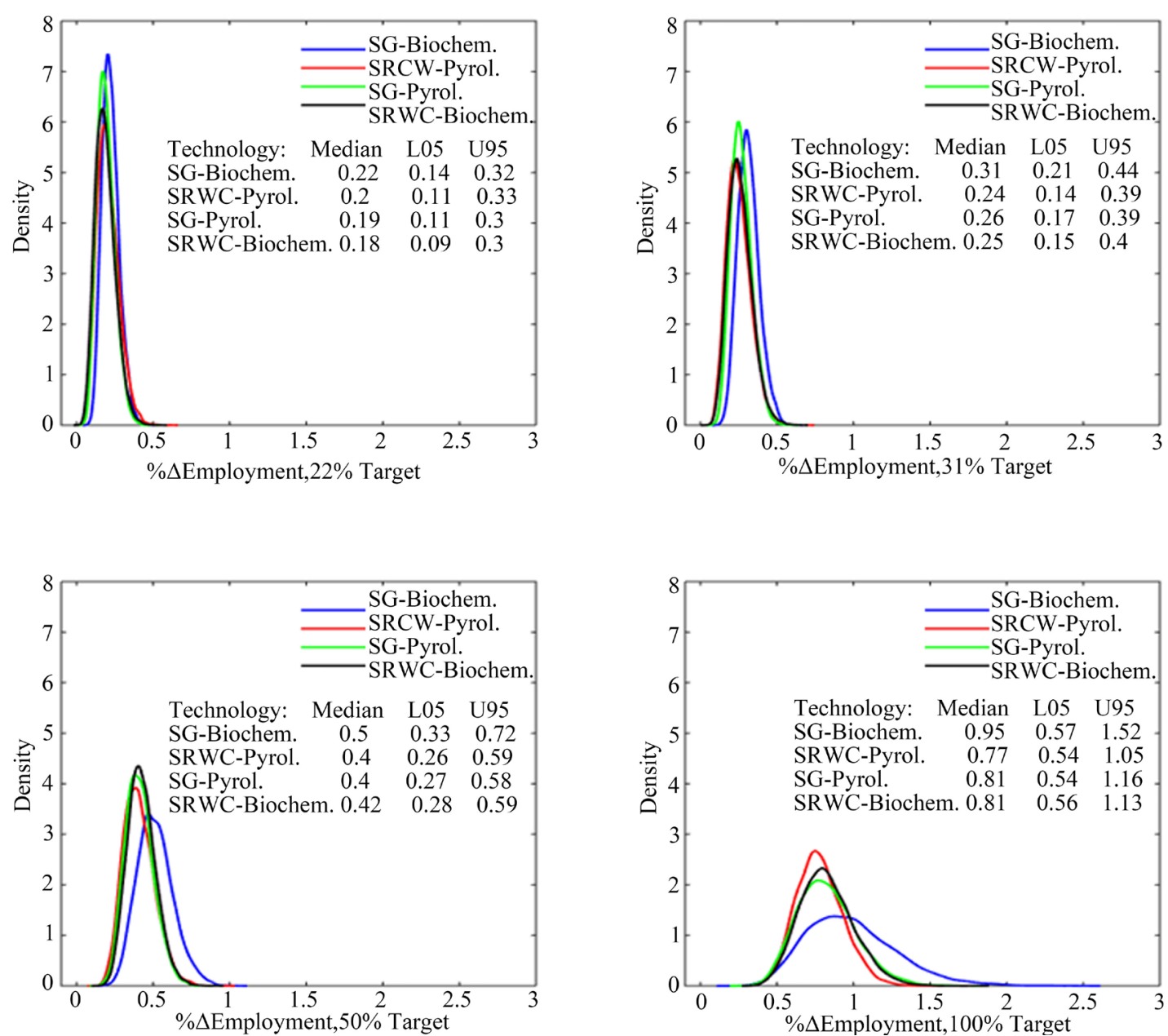

Figure 3. Simulated distributions of the percent change in employment from the baseline number of jobs following the introduction of biofuels produced by biochemical and pyrolysis technologies (22\%, 31\%, $50 \%$ and $100 \%$ of the RFS2 mandate). Key: SG, switchgrass; SRWC, short rotation woody crops (poplar).

conversion system, requiring less biomass for conversion. Less biomass demanded translates into compact feedstock sheds, and potentially less economic impact. For the biochemical conversion process using SRWC, the displacement of conventional crops by SRWC is less extensive (compared with switchgrass), translating into lower (in relative magnitude) economic impacts for TVA and employment. However, these differences are indistinguishable at $22 \%$ and $31 \%$ of the regional target.

Across all technologies, there were 46 to 58 jobs generated per 100 bil. Btu under the different target levels (Table 3, the job/Btu ratios are rescaled by 100 bil.). In general, the jobs 100 bil. Btu ${ }^{-1}$ ratios decreased as the full implementation target of 10.5 bgy is approached. This likely occurs because, at the extensive margin of feedstock producing areas (e.g., more rural areas), baseline employment is generally lower. The impact for biochemical ethanol (switchgrass feedstock) is relatively higher because of facility capacity requirements and the type of land converted to meet feedstock demand. The jobs per Btu ratio for ethanol produced using switchgrass and the biochemical pathway dominated the same ratio for the other technologies at all levels of the targets evaluated, ranging between 57.74 jobs 100 bil. Btu $^{-1}$ (at 22\% of the mandate) to 55.95 jobs 100 bil. Btu $^{-1}$ (at 100\% of the mandate).

Ratios of total value added to the regional economy and Btu's $(100,000 \mathrm{~s}, 100 \mathrm{~K})$ were evaluated for each the technology/feedstock combinations at 22\%, 31\%, 50\%, and 100\% achievement of the 10.5 bgy RFS2 target (Table 3). These indicators are interpreted as dollar values added to the economy per $100 \mathrm{~K} \cdot \mathrm{Btu}$ generated by mandate. Across all technologies and feedstocks, the value added $100 \mathrm{~K} \cdot \mathrm{Btu}^{-1}$ ranged between 2.89 and 3.84 . The variation in these indicators is due to the tradeoff between feedstock transport costs, land productivity, and 

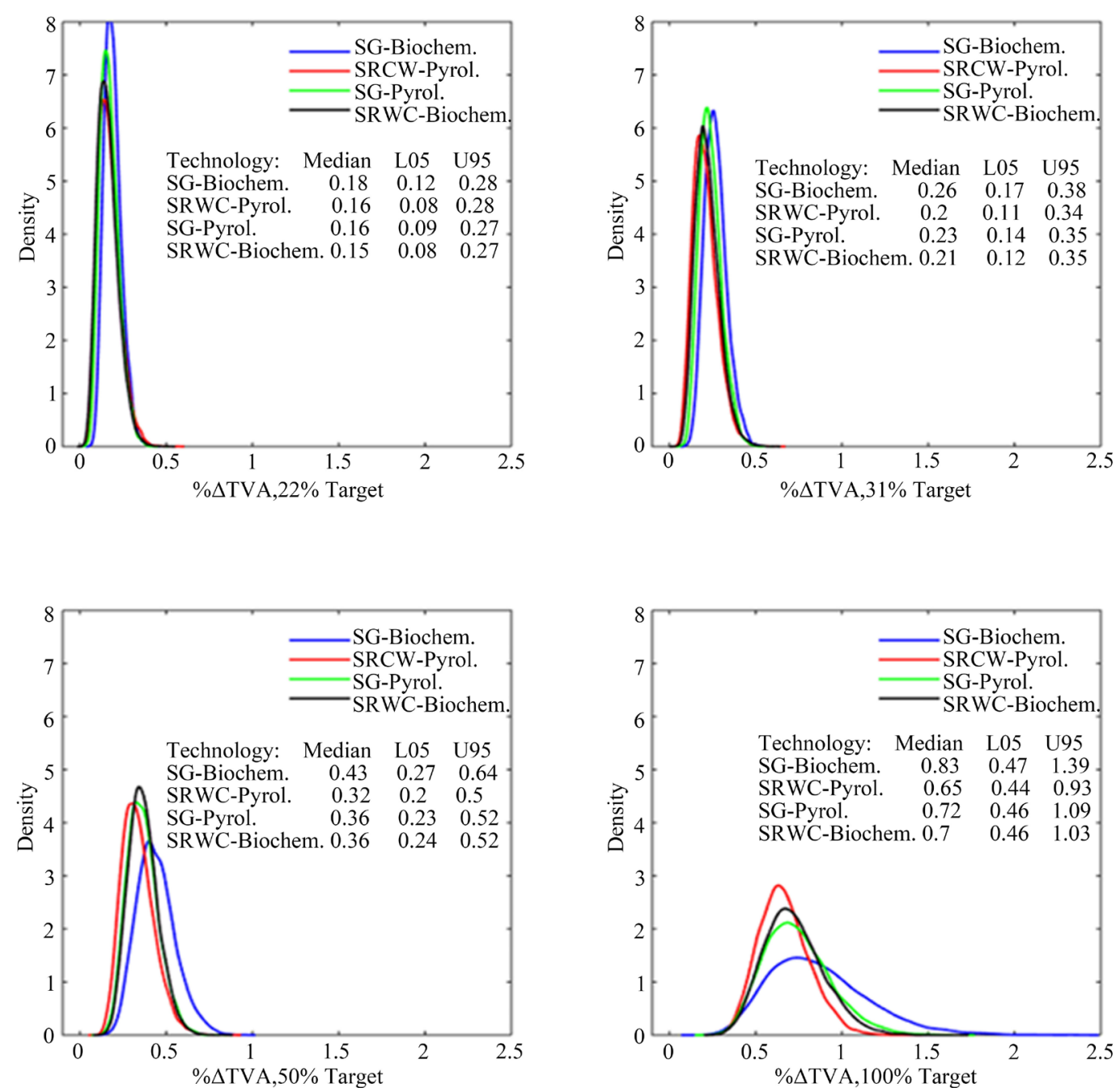

Figure 4. Simulated distributions of the percent change in total value added (TVA) from the baseline TVA following the introduction of biofuels produced by biochemical and pyrolysis (22\%, 31\%, 50\% and $100 \%$ of the RFS2 mandate). Key: SG, switchgrass; SRWC, short rotation woody crop (poplar).

Table 3. Total value added and employment and Btu’s.

\begin{tabular}{|c|c|c|c|c|}
\hline & \multicolumn{4}{|c|}{---10 } \\
\hline & $22 \%$ & $31 \%$ & $50 \%$ & $100 \%$ \\
\hline \multicolumn{5}{|c|}{ Employment/100 bil. Btu } \\
\hline \multicolumn{5}{|l|}{ Fuel/technology/feedstock: } \\
\hline Ethanol/Biochem./Switchgrass & 57.74 & 57.8 & 58.36 & 55.95 \\
\hline Ethanol/Biochem./SRWC & 48.54 & 47.46 & 48.41 & 46.82 \\
\hline Drop-in (pyrolysis)/SRWC & 53.36 & 46.31 & 46.27 & 44.24 \\
\hline Drop-in (pyrolysis)/Switchgrass & 49.41 & 48.98 & 46.87 & 46.66 \\
\hline \multicolumn{5}{|c|}{ Total value added/100,000 Btu } \\
\hline \multicolumn{5}{|l|}{ Fuel/technology/feedstock: } \\
\hline Ethanol/Biochem./Switchgrass & 3.77 & 3.76 & 3.84 & 3.75 \\
\hline Ethanol/Biochem./SRWC & 3.19 & 3.09 & 3.2 & 3.13 \\
\hline Drop-in (pyrolysis)/SRWC & 3.31 & 2.91 & 2.92 & 2.89 \\
\hline Drop-in (pyrolysis)/Switchgrass & 3.36 & 3.33 & 3.18 & 3.23 \\
\hline
\end{tabular}


the distribution of facilities. The TVA $100 \mathrm{~K} \cdot \mathrm{Btu}^{-1}$ generated by the biochemical technology option (switchgrass feedstock) dominated the other technologies, ranging between $\$ 3.75100 \mathrm{~K} \cdot \mathrm{Btu}^{-1}$ (at $100 \%$ of the mandate) to $\$ 3.84100 \mathrm{~K} \cdot \mathrm{Btu}^{-1}$ (at $50 \%$ of the 10.5 bgy target).

As the variability of the simulated employment $\mathrm{Btu}^{-1}$ and TVA $100 \mathrm{~K} \cdot \mathrm{Btu}^{-1}$ distributions suggest, it is difficult to discern a clear advantage with respect to jobs or total value added to the economy generated by each technology/feedstock combinations (Figure 5 and Figure 6). However, as the $100 \%$ target is approached, the distributions generated from the switchgrass-ethanol scenario are skewed right. The rightward shift in the distribution is due to the scale of the plants assumed for the biochemical conversion process, and forward economic links switchgrass production transport, and storage has with the regional economy.

\section{Conclusions}

From the perspective of investors, the decision to select a location is influenced by the expected cost savings arising from the external economies that emerge from the up- and downstream linkages which define the bioenergy sectors. From the perspective of rural communities, local planners require timely information about which community attributes they can leverage to attract and retain businesses and the jobs they support as bioenergy sectors develop. This research analyzed 1) the economic linkages between the agriculture sector and
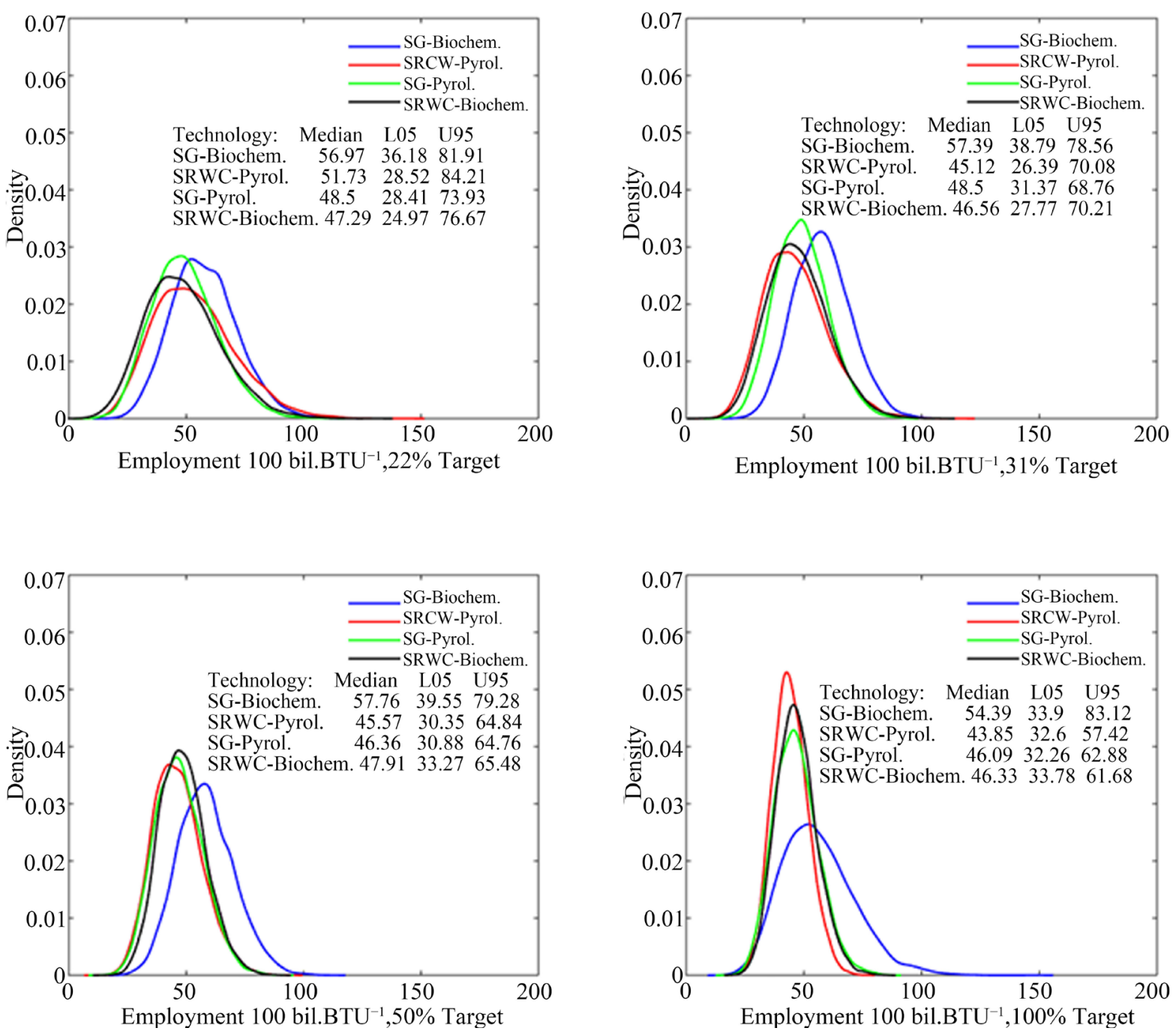

Figure 5. Simulated distributions of changes in employment per energy unit (100 bil. Btu) following the introduction of biofuels produced by biochemical and pyrolysis technologies (22\%, 31\%, 50\% and $100 \%$ of the RFS2 mandate). Key: SG, switchgrass; SRWC, short rotation woody crop (poplar). 

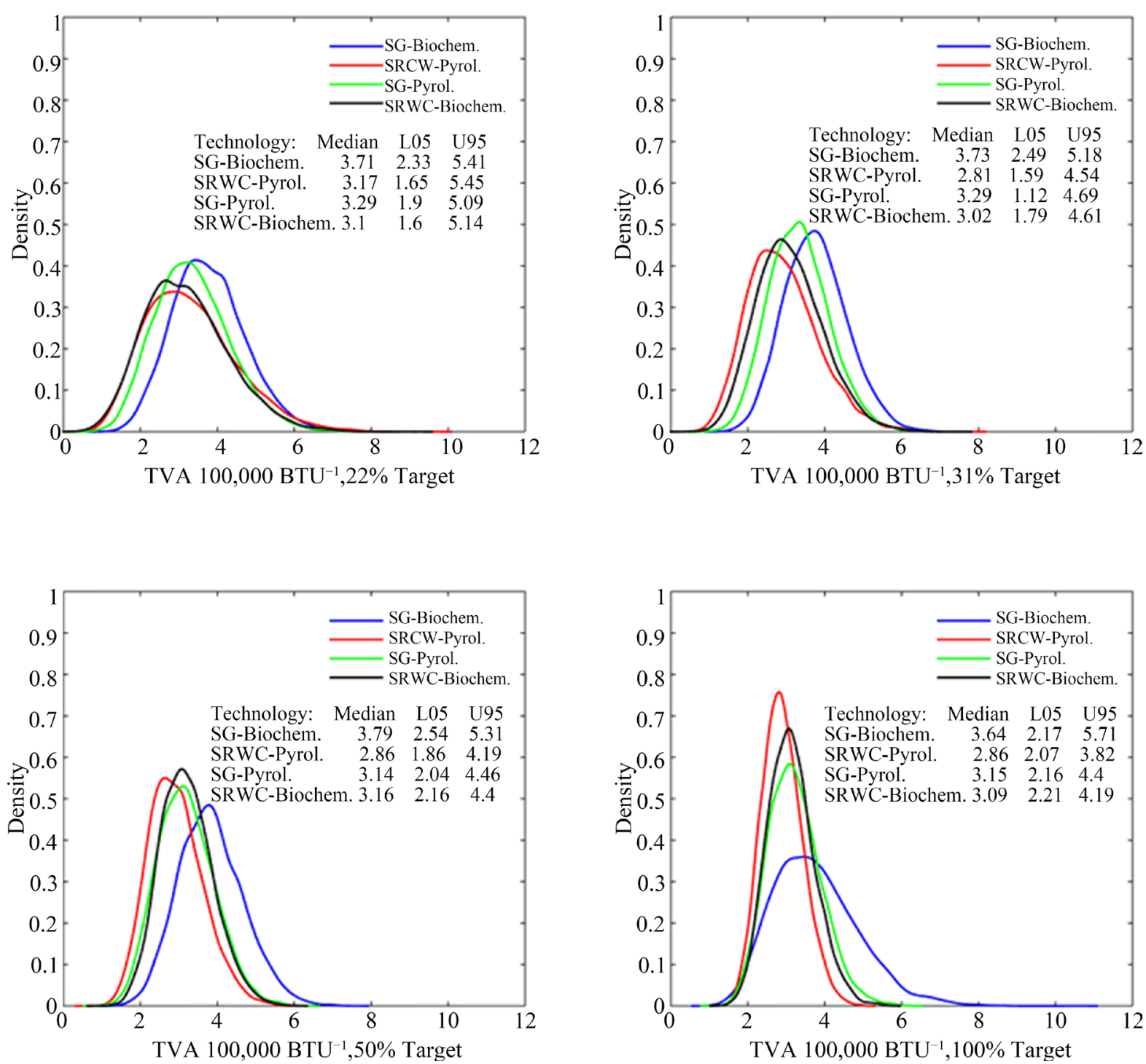

Figure 6. Simulated distributions of changes in total value added per energy unit (100,000 Btus) following the introduction of biofuels produced by biochemical and pyrolysis technologies (22\%, 31\%, 50\% and 100\% of the RFS2 mandate). Key: SG, switchgrass; SRWC, short rotation woody crop (poplar).

two emerging biomass-bioenergy sectors-biochemical production of ethanol, and pyrolysis-using switchgrass and the short rotation woody crop, poplar, and 2) the potential impact of these activities on rural economies given federal mandates encouraging the production of advanced biofuels.

Information about suitability of potential locations for conversion facilities will be helpful for siting facilities and determining feedstock sheds. Factors influencing the location of conversion facilities include assessment of potential feedstock availability and logistics costs as investors seek least-cost sites. Local comparative advantage will be driven by skilled work force availability, access to capital, and infrastructure. But the socioeconomic and environmental impacts of an expanding second generation fuels complex remain unclear as new demands on agriculture and forestlands arise, and as primary and secondary road traffic increases.

While the net effects of the technologies and feedstock analyzed in this paper are positive for the regional economy, the effects of spatial competition for limited feedstock resources have on job, income, and business establishment growth will likely vary, depending on the competiveness of a county and its ability to leverage local resources or its connection to wider economies. The findings of this research are driven by primary data sources, but also key assumptions about the capacity, scale, and efficiency of the technologies evaluated. As 
these technologies mature, the relative costs of the technologies may change. These changes would impact the economic indicators analyzed, and potentially rankings of the regional impacts the technologies have on local economies.

\section{Acknowledgements}

Research was supported by the United States Department of Agriculture-National Institute of Food and Agriculture grant awards \#11025775 and \#2011-68005-30410, which supports the Integrate Biomass Supply System research. Funding was also made available by the United States Geological Survey and the University of Tennessee Water Resources Research Institute Program. The authors thank anonymous reviewers for comments and suggestions. The views are those of the authors.

\section{References}

[1] Perlack, R. and Stokes, B. (2011) U.S. Billion Ton Update: Biomass Supply for Bioenergy and Bioproducts Industry. U.S. Department of Energy, Energy Efficiency and Renewable Energy.

[2] English, B.C., De La Torre Ugarte, D., Walsh, M., Hellwinckel, C. and Menard, J. (2006) Economic Competitiveness of Bioenergy Production and Effects on Agriculture of the Southern Region. Journal of Agricultural and Applied Economics, 38, 389-402.

[3] U.S. Congress (2007) Energy Independence and Security Act of 2007. Public Law 110-140, Washington DC, 110th Cong., 1st Sess., December 19, Title II, Sec. 202.

http://www.nems.nih.gov/Pages/ENERGY-INDEPENDENCE-AND-SECURITY-ACT-2007-.aspx

[4] United States Department of Agriculture (2010) USDA Regional Roadmap to Meeting the Biofuels Goals of the Renewable Fuels Standard by 2022. www.usda.gov/documents/USDA_Biofuels_Report_6232010.pdf

[5] Lambert, D.M., Wojan, T.R. and Sullivan, P. (2009) Farm Business and Household Expenditure Patterns and Local Communities: Evidence from a National Farm Survey. Review of Agricultural Economics, 31, 604-626. http://dx.doi.org/10.1111/j.1467-9353.2009.01456.x

[6] Parcell, J.L. and Westhoff, P. (2006) Economic Effects of Biofuel Production on States and Rural Communities. Journal of Agricultural and Applied Economics, 38, 377-387.

[7] Novack, N. and Henderson, J. (2007) Can Ethanol Power the Rural Economy? The Main Street Economist, 2, 1-6.

[8] Swenson, D. and Eathington, L. (2006) A Summary of Findings: Determining the Regional Economic Values of Ethanol Production in Iowa Considering Different Levels of Local Investment. Report BIOE2006-01. Department of Agricultural Economics, Iowa State University, July.

[9] Shapouri, H. and Gallagher, P. (2005) USDA’s 2002 Ethanol Cost-of-Production Survey. U.S. Department of Agriculture, Washington DC, ESCS For. Agr. Econ. Rep. 841, July.

[10] English, B.C., De La Torre Ugarte, D., Jensen, K., Hellwinckel, C., Menard, J., Wilson, B., Roberts, R. and Walsh. M. (2006) 25\% Renewable Energy for the United States by 2025: Agricultural and Economic Impacts. Bio-Based Energy Analysis Group, Department of Agriculture \& Resource Economics, The University of Tennessee.

[11] United States Department of Agriculture (2011) Farm Services Agency. Biomass Crop Assistance Program (BCAP) Fact Sheet U.S. Department of Agriculture, Washington D.C.

https://www.fsa.usda.gov/Internet/FSA File/bcap areas2 5 2011.pdf

[12] Olson and Lindall (1999) IMPLAN Users Manual.

[13] Lazarus, W. and Tiffany, D. (2009) Economic Impacts of Establishing Short Rotation Woody Crops to Support Energy Production in Minnesota. Staff Paper Series, P09-2.

[14] English, B.C., Menard, J. and De La Torre Ugarte, D. (2004) Using Corn Stover for Ethanol Production: A Look at the Regional Economic Impacts for Selected Midwestern States. Bio-Based Energy Analysis Group, Department of Agriculture \& Resource Economics, The University of Tennessee.

[15] Hughes, D. and Hinson, R. (2000) Estimating the Value of the Green Industry to Louisiana's Economy. Journal of Agribusiness, 18, 207-220.

[16] Turner, S. and Kreisel, W. (1995) The Relative Importance of the Green Industry in the US Agricultural Economy. Journal of Agribusiness, 13, 51-62.

[17] Swenson, D. (2006) Input-Outrageous: The Economic Impact of Modern Biofuels Production. http://nercrd.psu.edu/Biofuels/Swenson.pdf

[18] Low, S.A. and Isserman, A.M. (2009) Ethanol and the Local Economy: Industry Trends, Location Factors, Economic 
Impacts, and Risks. Economic Development Quarterly, 23, 71-88. http://dx.doi.org/10.1177/0891242408329485

[19] Lambert, D.M., Cavasos, C., Wilson, B., Clark, C.D. and English, B.C. (2016) Projected Changes in Stream System Nitrogen Runoff Associated with a Mature Cellulosic Ethanol Industry in the Southeastern United States. Land Use Policy, 56, 291-302. http://dx.doi.org/10.1016/j.landusepol.2016.04.019

[20] McDaniels, P. (2016) Taking a Next Step toward a Biobased Economy. Tennessee Alumnus, May 2016, http://alumnus.tennessee.edu/2016/taking-a-next-step-toward-a-biobased-economy/?utm_source=utaa\&utm_medium= email\&utm_term=genera\&utm_content=text\&utm_campaign=spring2016_alumni

[21] Alternative Fuels Data Center (AFDC) (2011) Biobutanol Benefits. http://www.afdc.energy.gov/afdc/fuels/emerging_biobutanol_benefits.html

[22] BBI International (2002) State of Maine Ethanol Pre-Feasibility Study. Prepared for Finance Authority of Maine.

[23] EPRI. (2007) Renewable Energy Technical Assessment Guide-TAG-RE: 2006, EPRI, Palo Alto, CA. http://www.epri.com/abstracts/Pages/ProductAbstract.aspx?ProductId=000000000001012722

[24] Fortenberry, T. (2005) Biodiesel Feasibility Study: An Evaluation of Biodiesel Feasibility in Wisconsin. University of Wisconsin-Madison, Department of Agricultural \& Applied Economics, Staff Paper No. 481.

[25] McAloon, A., Taylor, F., Yee, W., Ibsen, K. and Wooley, R. (2000) Determining the Cost of Producing Ethanol from Corn Starch and Lignocellulosic Feedstocks. National Renewable Energy Laboratory (NREL/TP-580-28893).

[26] Wright, M., Satrio, J., Brown, R., Daugaard, D. and Hsu, D. (2010) Techno-Economic Analysis of Biomass Fast Pyrolysis to Transportation Fuels. Golden, CO: US Department of Energy, Office of Energy Efficiency \& Renewable Energy, Technical Report NREL/TP-6A20-46586.

[27] Humbird, D., Davis, R., Tao, L., Kinchin, C., Hsu, D., Aden, A., Schoen, P., Lukas, J., Olthof, B., Worley, M., Sexton, D. and Dudgeon, D. (2011) Process Design and Economics for Biochemical Conversion of Lignocellulosic Biomass to Ethanol, Dilute-Acid Pretreatment and Enzymatic Hydrolysis of Corn Stover. NREL Technical Report, NREL/TP5100-47764, May 2011.

[28] Energy Information Administration and US Department of Energy (2011) Form EIA-860 Annual Electric Generator Report. http://www.eia.doe.gov/cneaf/electricity/page/eia860.html

[29] Wilson, B. (2009) Modelling Cellulosic Ethanol Plant Location Using GIS. MS Thesis, The University of Tennessee, Knoxville.

[30] English, B., Yu, T.-H., Yu, E., Larson, J., Menard, J. and Gao, Y. (2013) Economic Impacts of Using Switchgrass as a Feedstock for Ethanol Production: A Case Study Located in East Tennessee. Economics Research International, 2013, Article ID: 138485. http://dx.doi.org/10.1155/2013/138485

[31] ESRI (2008) Environmental Sensitivities Research Institute. http://www.esri.com/

[32] National Agricultural Statistics Service (NASS) (2010) Cropland Data Layer. www.nass.usda.gov/research/Cropland/SARS1a.htm

[33] Slinsky, S.P. and Tiller, K.H. (1999) Application of an Alternative Methodological Approach for Budget Generators for Research, Published Abstract. Journal of Agricultural and Applied Economics, 31, 401.

[34] Hellwinckel, C.M. (2015) Spatial Interpolation of Crop Budgets: Documentation of POLYSYS Regional Budget Estimation, Version 1.0.

[35] Perlack, R., Stokes, B., Hellwinckel, C., and De La Torre Ugarte, D. (2011) US Billion-Ton Update: Biomass Supply for a Bioenergy and Bioproducts Industry. US Department of Energy, Perlack, R.D. and Stokes B.J. (Leads), ORNL/TM-2011/224, Oak Ridge National Laboratory, Oak Ridge, TN, 227p.

[36] Turhollow, A., Perlack, R., Eaton, L., Langholtz, M., Brandt, C., Downing, M., Wright, L., Skog, K., Hellwinckel, C.M., Stokes, B. and Lebow, P. (2015) The Updated Billion-Ton Resource Assessment. Biomass and Bioenergy, 70, 149-164. http://dx.doi.org/10.1016/j.biombioe.2014.09.007

[37] Efron, B. and Tibshirani, R.J. (1993) An Introduction to the Bootstrap. Chapman and Hall, New York. 


\section{Submit or recommend next manuscript to SCIRP and we will provide best service for you:}

Accepting pre-submission inquiries through Email, Facebook, Linkedin, Twitter, etc A wide selection of journals (inclusive of 9 subjects, more than 200 journals)

Providing a 24-hour high-quality service

User-friendly online submission system

Fair and swift peer-review system

Efficient typesetting and proofreading procedure

Display of the result of downloads and visits, as well as the number of cited articles

Maximum dissemination of your research work

Submit your manuscript at: http://papersubmission.scirp.org/ 